EDUCATIONAL : Jurnal Inovasi Pendidikan dan Pengajaran

Vol. 1 No. 4 November 2021 e-ISSN : 2775-2593 | p-ISSN : 2775-2585

\title{
PENINGKATAN HASIL BELAJAR MATERI REAKSI REDOKS MELALUI MODEL PEMBELAJARAN PROBLEM SOLVING PADA SISWA KELAS X MIPA 3 SMAN I KEMBANGBAHU LAMONGAN
}

\author{
ENI PURWANTI \\ SMA Negeri 1 Kembangbahu Lamongan \\ Email : enipurwanti54@guru.sma.belajar.id
}

\begin{abstract}
ABSTRAK
Penelitian ini bertujuan untuk mengetahui penerapan model pembelajaran problem solving dalam meningkatkan hasil belajar kimia pada materi reaksi redoks siswa Kelas X MIPA 3 SMA Negeri 1 Kembangbahu Lamongan provinsi Jawa Timur. Penelitian dilaksanakan pada semester genap tahun pelajaran 2019/2020. Jenis penelitian ini adalah penelitian tindakan kelas (PTK) yang terdiri terdiri atas empat tahap, yaitu perencanaan, pelaksanaan tindakan, pengamatan dan refleksi. Penelitian ini menggunakan 2 siklus tindakan. Teknik pengumpulan data menggunakan: observasi, tes, catatan lapangan dan dokumentasi. Model pembelajaran Problem solving diterapkan dengan cara, siswa dihadapkan pada suatu masalah, kemudian diminta untuk memecahkannya secara berkelompk. Kemampuan siswa dalam memahami pelajaran melalui model problem solving dapat dilihat dari hasil tes. Pemberian tes dilakukan dua tahap yaitu tes siklus I, dan tes siklus II. Berdasarkan hasil tes siswa diperoleh ketuntasan secara klasikal sebesar $75 \%$ pada siklus I dan $85 \%$ pada siklus II. Berdasarkan hasil penelitian, maka dapat disimpulkan bahwa dengan menggunakan model pembelajaran problem solving dapat meningkatkan hasil belajar kimia siswa Kelas X MIPA 3 SMA Negeri 1 Kembangbahu Lamongan semester genap tahun pelajaran 2019/2020 pada materi reaksi redoks.
\end{abstract}

Kata Kunci: hasil belajar, reaksi redoks, model pembelajaran problem solving

\section{ABSTRACT}

This study aims to determine the application of problem solving learning models in improving chemistry learning outcomes in redox reaction material for students of Class X MIPA 3 SMA Negeri 1 Kembangbahu Lamongan, East Java province. The research was carried out in the even semester of the 2019/2020 school year. This type of research is classroom action research (CAR) which consists of four stages, namely planning, implementing actions, observing and reflecting. This study uses 2 cycles of action. Data collection techniques used: observation, tests, field notes and documentation. Problem solving learning model is applied in a way, students are faced with a problem, then asked to solve it in groups. Students' ability to understand lessons through problem solving models can be seen from the test results. The test was administered in two stages, namely the first cycle test and the second cycle test. Based on the results of student tests, classical completeness was $75 \%$ in the first cycle and $85 \%$ in the second cycle. Based on the results of the study, it can be concluded that using a problem solving learning model can improve chemistry learning outcomes for Class X MIPA 3 students at SMA Negeri 1 Kembangbahu Lamongan in the even semester of the 2019/2020 school year on redox reaction material.

Keywords: learning outcomes, redox reactions, problem solving learning models

\section{PENDAHULUAN}

Ilmu kimia adalah ilmu yang mempelajari mengenai komposisi, struktur, dan sifat zat atau materi dari skala atom hingga molekul serta perubahan atau transformasi serta interaksi mereka untuk membentuk materi yang ditemukan sehari-hari. Ilmu kimia bersifat abstrak dan memerlukan keaktifan siswa dalam memecahkan berbagai masalah dalam persoalan yang berhubungan dengan kimia baik dalam ruang lingkup sekolah maupun diluar ruang lingkup sekolah (sehari- hari). Kimia pada tingkat sekolah sudah mulai diajarkan pada tingkat sekolah atas. 


\section{Vol. 1 No. 4 November 2021 e-ISSN : 2775-2593 | p-ISSN : 2775-2585}

Salah satu materi kimia yang capaian hasilbelajarnya rendah adalah konsep reaksi reduksi oksidasi ( redoks ) Materi reaksi redoks merupakan salah satu materi pada pokok dalam ilmu kimia yang dibahas pada semester genap kelas X. tingkat sekolah menengah atas. Reaksi reaksi redoks sangat mudah dijumpai dalam kehidupan sehari- hari. Perkaratan besi, perubahan warna daging apel menjadi kecokelatan kalau dikupas merupakan contoh peristiwa oksidasi. (Sudarmo, 2013 ). Namun pada materi ini masih banyak siswa yang masih bingung menentukan bilangan oksidasi. Siswa juga kebingungan dalam perhitungan sederhana pengurangan atau penjumlahan bilangan positif dan negatif sehingga pengaplikasian untuk menentukan reaksi yang terjadi pada reaksi oksidasi atau reduksi menjadi keliru, sehingga hasil ulangan harian untuk materi redoks masih belum memenuhi ketuntasan minimal. Hal ini diperkuat hasil ulangan harian siswa SMA Negeri I Kembangbahu beberapa tahun terakhir hanya $40 \%$ siswa yang tuntas, sehingga siswa yang belum tuntas mencapai $60 \%$. Perlu diketahui bahwa standar kriteria ketuntasan maksimal (KKM)sekolah sebesar 68. Kenyataan ini menunjukkan bahwa siswa masih kurang mampu menyerap materi yang diajarkan. Sungguh merupakan suatu masalah serius yang patut mendapat penanganan secara tepat.Sehingga guru harus mempunyai strategi dan pendekatan tertentu kepada siswa yang bertujuan untuk meningkatkan hasil belajarnya melalui proses pemecahan masalah.

Berdasarkan permasalahan tersebut maka perlu diupayakan suatu model pembelajaran yang dapat meningkatkankemampuan siswa untukmengerjakan soal pada materi kimia yangberkaitan dengan konsep serta hitungan. Model pembelajaran yang dapatditerapkan adalah model problem solving. Model problem solving menuntut siswa untuk berpikir sistematis dan kritis, terampil dalam memecahkan soal, dan dapat mengambil keputusan yang objektif

Menurut Maryam (2019) yang menyatakan bahwa problem solving merupakan salah satu metode yang dapat membelajarkan siswa secara individu maupun kelompok untuk memecahkan masalah menggunakan pengetahuannya. Model pembelajaran problem solving merupakan suatu model yang mandiri dimana para siswa dituntut berpikir kritis, terampil dalam memecahkan soal, dapat mengambil keputusan yang objektif dan dapat membina pengembangan sikap perasaan (ingin tahu lebih jauh). Hal ini dapat mempengaruhi tingkat kesadaran siswa dalam belajar dan meningkatkan nilai siswa di sekolah. Penerapan model pembelajaran problem solving dikarenakan beberapa alasan seperti, apabila siswa hanya menyimak, mencatat dan mendengar mereka merasa jenuh dan bosan.

Selain itu penelitian yang dilakukan oleh Rosniar (2018) menyatakan bahwa metode pembelajaran problem solving dapat meningkatkan hasil belajar siswa pada materi konsep mol.Berdasarkan pemikiran tersebut, dilakukan penelitian tindakan kelas tentang Penerapan Model Pembelajaran Problem Solving Untuk Meningkatkan Hasil Belajar Siswa Pada Materi Reaksi Redoks Di Kelas X MIPA 3 SMAN I Kembangbahu Lamongan.

\section{METODE PENELITIAN}

Penelitian ini menggunakan rancangan penelitian tindakan kelas (classroom action research yang dilakukan dengan tujuan untuk meningkatkan wawasan tentang perilaku guru dalam mengajar dan memperbaiki kualitas hasil pembelajaran dikelas. Menurut Kemmis dan Mc Taggart (dalam Asrori, 2008:68), terdapat empat tahapan yang harus dilaksanakan dalam penelitian tindakan kelas, diantaranya : (1) Perencanaan, (2) Pelaksanaan, (3) Pengamatan, dan (4) Refleksi.Data penelitian diperoleh dari siswa SMA Negeri I tahun ajaran 2019/2020 pada kelas X-MIPA 3 yang berjumlah 30 siswa terdiri dari 13 siswa laki-laki dan 17 siswa perempuan. Adapun rancangan penelitian ini dapat digambarkan dalam bagan berikut : 


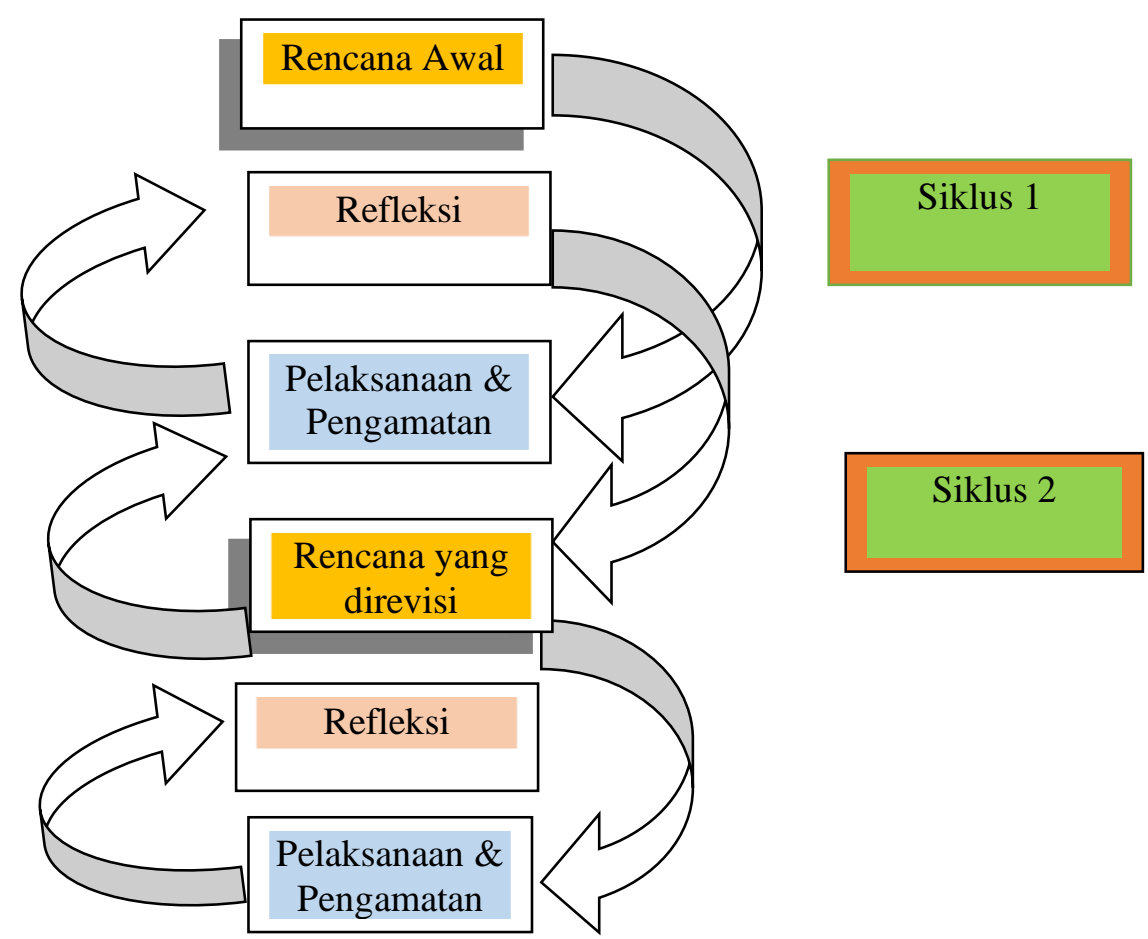

Gambar 1. Bagan rancangan pelaksanaan PTK

(Arikunto, $137: 2010$ )

Berdasarkan alur penelitian, instrumen penelitian yang digunakan dalam penelitian ini diantaranya : ( 1) Perangkat pembelajaran yang meliputi : RPP, silabus, daftar hadir, dan soal evaluasi siklus I dan siklus II (2) Lembar observasi dan (3) Evaluasi hasil pembelajaran. Sedangkan teknik pengambilan data dilakukan dilakukan melalui observasi dan evaluasi hasil belajar, kemudian data dianalisis dengan menggunakan rumus persentase aktivitas belajar siswa dan persentase hasil belajara siswa. Adapun rumus untuk menentukan aktivitas belajar siswa adalah : $\%=$ $\frac{\sum \text { skor perolehan }}{\sum \text { skor maksmimal }} \times 100 \%$, dan kriteria ketercapaian dapat dilihat dalam tabel berikut :

Tabel 1. Kriteria Aktivitas Belajar Siswa

\begin{tabular}{|l|l|}
\hline Persentase & Kategori \\
\hline$<25 \%$ & Kurang Aktif \\
\hline $26 \%-50 \%$ & Cukup Aktif \\
\hline $51 \%-75 \%$ & Aktif \\
\hline $76 \%-100 \%$ & Sangat Aktif \\
\hline
\end{tabular}

(Diadaptasi dari Sumarno,67 : 2012)

Sedangkan siswa dikatakan tuntas belajarnya (tuntas individu) jika proporsi jawaban siswa yang benar $\geq 68$, sedangkan ketuntasan klasikal tercapai jika dalam satu kelas tersebut terdapat $\geq 85 \%$ siswa telah tuntas belajarnya, (Trianto, 2012 : 241) Analisis data dihitung dengan menggunakan rumus : $\%=\frac{\sum \mathrm{Ns}}{\sum \mathrm{Sp}} \times 100 \%$

Keterangan :

Ns : nilai yang diperoleh siswa

Sp : jumlah skor maksimal 


\section{Vol. 1 No. 4 November 2021 e-ISSN : 2775-2593 | p-ISSN : 2775-2585}

Ts : jumlah total skor

Adapun indikator keberhasilan kinerja dalam penelitian ini tertera dalam tabel 2 berikut :

Tabel 2. Indikator Keberhasilan Kinerja dalam Penelitian

\begin{tabular}{|l|l|l|}
\hline $\begin{array}{l}\text { Aspek yang } \\
\text { dinilai }\end{array}$ & Target & Cara Penilaian \\
\hline Aktivitas siswa & $\begin{array}{l}75 \% \text { (kategori } \\
\text { baik) }\end{array}$ & $\%=\frac{\sum \text { skor perolehan }}{\sum \text { skor maksmimal }} \times 100 \%$ \\
\hline $\begin{array}{l}\text { HasilBelajar } \\
\text { Klasikal }\end{array}$ & $\begin{array}{l}85 \% \text { (kategori } \\
\text { baik) }\end{array}$ & $\%=\frac{\sum \text { skor perolehan }}{\sum \text { skor maksmimal }} \times 100 \%$ \\
\hline
\end{tabular}

\section{HASIL DAN PEMBAHASAN}

Hasil penelitian ini ditemukan bahwa penerapan model pembelajaran problem solving dapat meningkatkan hasil belajar siswa.

Adapun uraian pelaksanaan setiap tindakan adalah sebagai berikut:

\section{I . Siklus I}

Pada tahap perencanaan kegiatan yang dilakukan adalah : a). Membuat RPP yang didalamnya terdapat materi tentang konsep reaksi redoks b). Menyiapkan Lembar Kerja Siswa (LKS) c). Membuat Evaluasi Hasil Belajar d). Menyiapkan lembar observasi aktivitas siswa .

Pada tahap pelaksanaan peneliti membagi ke dalam tiga pertemuan. Pertemuan ke-1 guru sekaligus bertindak sebagai peneliti membahas materi tentang, konsep reaksi redoks berdasarkan tiga aspek pelepasan dan penangkapan oksigen, pelepasan dan penangkapan elektron, dan kenaikkan dan penurunan biloks, Pada awal pembelajaran, setiap aspek pengamatan masih belum dapat berjalan dengan baik. Selama pembelajaran, suasana kelas yang kurang kondusif membuat siswa kurang memperhatikan penjelasan guru, sehingga interaksi yang terjadi kurang baik dan pembelajaran yang kurang sesuai dengan yang direncanakan dalam RPP. Hal ini terlihat pada hasil prosentase aktivitas siswa sebesar $68 \%$ dengan kategori yang diperoleh pada pertemuan pertama sebesar $71 \%$ berkategori "sangat tinggi." Pada pertemuan berikutnya, suasana kelas semakin kondusif, siswa mulai aktif dan lebih memiliki sikap percaya diri dalam menyampaikan gagasan, hasil diskusi ataupun pengamatan yang telah dilakukan.

Pada pertemuan ke-2 guru membahas materi tentang penentuan biloks atom dalam senyawa atau ion. Sedangkan untuk pertemuan ke-3 guru memberikan lembar evaluasi siklus I. Langkah pembelajaran disesuaikan dengan model pembelajaran problem solving yaitu siswa duduk pada kelompok masing-masing, kemudian guru membagikan LKS. Setiap kelompok berdiskusi untuk menyelesaikan masalahnya, jika siswa mengalami kesulitan dalam mengerjakan LKS guru membimbingnya dengan mengajukan pertanyaan-pertanyaan yang mengarah agar siswa bisa menyelesaikan permasalahan.

Kegiatan dilanjutkan dengan pemaparan hasil kerja kelompok. Salah satu kelompok tampil mempresentasikan hasil diskusinya dan kelompok lain menanggapinya. Setelah selesai presentasi dan siswa menanggapi, peneliti memberikan skor untuk masing-masing kelompok berdasarkan jawaban yang ada di LKS, kemudian guru memberikan penghargaan kepada siswa yang aktif dan berprestasi serta memberikan semangat kepada siswa yang kurang aktif.

Pertemuan ke -3 diadakan tes akhir (post test) siklus I. Tes ini diikuti oleh 30 siswa.

Berdasarkan tes hasil belajar siklus I, terdapat 19 siswa yang tuntas dan 11 orang siswa yang belum mencapai ketuntasan belajar secara individu yaitu siswa yang memperoleh nilai < 68 sesuai dengan KKM pada materi reaksi redoks dengan nilai 68. Prosentase siswa yang sudah tuntas yaitu siswa yang memperoleh nilai $\geq 68$ adalah $\frac{19}{30} \times 100 \%=63 \%$ 


\section{Vol. 1 No. 4 November 2021 e-ISSN : 2775-2593 | p-ISSN : 2775-2585}

Sesuai dengan kriteria ketuntasan belajar secara klasikal di sekolah dinyatakan tuntas apabila 85\% siswa tuntas secara klasikal. Oleh karena itu, dapat disimpulkan bahwa ketuntasan belajar secara klasikal pada siklus I belum tercapai. Sedangkan hasil pengamatan terhadap aktivitas siswa keseluruhan memperoleh skor 19 sedangkan total skor 28, dengan persentase nilai rataratanya adalah: $\frac{19}{28} \times 100 \%=68 \%$

Dari data observasi di atas dapat disimpulkan bahwa aktifitas siswa pembelajaran siklus I berlangsung kurang memuaskan karena tidak sesuai dengan harapan peneliti dan perlu diperbaiki lagi pada siklus berikutnya, karena pada observasi siswa dengan persentase $68 \%$ belum mencapai batas indikator proses keberhasilan tindakan yaitu $85 \%$ untuk lebih jelasnya dapat disajikan dalam tabel berikut:

Tabel 3. Data Hasil Pengamatan Siklus I

\begin{tabular}{|l|l|l|l|}
\hline Aspek yang diamati & Perolehan & $\begin{array}{l}\text { Indikator } \\
\text { Keberhasilan }\end{array}$ & Keterangan \\
\hline Aktivitas Siswa & $68 \%$ & $75 \%$ & Belum Berhasil \\
\hline Hasil Belajar & $63 \%$ & $75 \%$ & Belum Berhasil \\
\hline
\end{tabular}

Berdasarkan hasil refleksi siklus I, dapat disimpulkan bahwa masih diperlukan perbaikan pada tindakan siklus berikutnya untuk meningkatkan hasil belajar siswa dalam kegiatan pembelajaran dengan menggunakan model pembelajaran problem solving.

\section{Siklus II}

Berdasarkan refleksi dari hasil siklus I , persentase nilai dari siklus I belum mencapai batas keberhasilan tindakan maka penelitian dilanjutkan dalam siklus II. Sebelum melaksanakan siklus II, peneliti terlebih dahulu juga mempersiapkan beberapa perangkat seperti yang dilakukan pada siklus I. Perbaikan yang dilakukan antara lain dengan lebih memotivasi dan menarik perhatian peserta didik pada materi yang sedang dibahas, terutama aspek-aspek yang masih belum optimal dilaksanakan.Pelaksanaan tindakan Siklus II dilaksanakan pada pertemuan ke-4. Langkah pembelajaran disesuaikan dengan model pembelajaran problem solving seperti yang dilakukan dalam siklus I hanya materi yang diajarkan berbeda yaitu tentang tata nama senyawa.

Pertemuan terakhir yaitu pertemuan ke-5. Pada pertemuan ini dilaksanakan tes akhir siklus II, Berdasarkan tes hasil belajar siklus II, terdapat 5 orang siswa yang belum mencapai ketuntasan belajar secara individu yaitu siswa yang memperoleh nilai $<68 \frac{25}{30} \times 100 \%=83 \%$ sesuai dengan KKM pada materi reaksi redoks dengan nilai 68 , dan siswa yang memperoleh nilai $\geq 68$ berjumlah 25 orang dengan persentase ketuntasan belajar sebesar

Sesuai dengan kriteria ketuntasan belajar secara klasikal di sekolah dinyatakan tuntas apabila 85\% siswa tuntas secara klasikal. Oleh karena itu, dapat disimpulkan bahwa ketuntasan belajar secara klasikal pada siklus II sudah tercapai. Sedangkan hasil pengamatan terhadap aktifitas keseluruhan memperoleh skor 24 sedangkan total skor 28 dengan persentase nilai rata-ratanya adalah: $\frac{24}{28} \times 100 \%=86 \%$

Sehingga dapat disimpulkan bahwa aktifitas siswa pembelajaran siklus II berlangsung sangat baik karena sudah melampaui batas indikator proses eberhasilan tindakan yaitu $75 \%$. Seperti yang disajikan dalam tabel berikut: 
EDUCATIONAL : Jurnal Inovasi Pendidikan dan Pengajaran

Vol. 1 No. 4 November 2021 e-ISSN : 2775-2593 | p-ISSN : 2775-2585

Tabel 4. Data Hasil Pengamatan Siklus II

\begin{tabular}{|l|l|l|l|}
\hline Aspek yang diamati & Perolehan & $\begin{array}{l}\text { Indikator } \\
\text { Keberhasilan }\end{array}$ & Keterangan \\
\hline Aktifitas Siswa & $86 \%$ & $75 \%$ & Berhasil \\
\hline Hasil Belajar & $83 \%$ & $85 \%$ & Cukup Berhasil \\
\hline
\end{tabular}

Berdasarkan hasil refleksi siklus II, dapat disimpulkan bahwa pembelajaran pada siklus II sudah mencapai keberhasilan baik dari segi proses maupun dari segi hasil jika dilihat dari kriteria yang telah diteliti yaitu aktivitas siswa selama pembelajaran dan hasil belajar siswa, terhadap penerapan model pembelajaran Problem Solving pada materi reaksi redoks.

Adapun peningkatan hasil belajar dan aktivitas siswa dalam siklus I sampai dan siklus II disajikan pada grafik berikut :

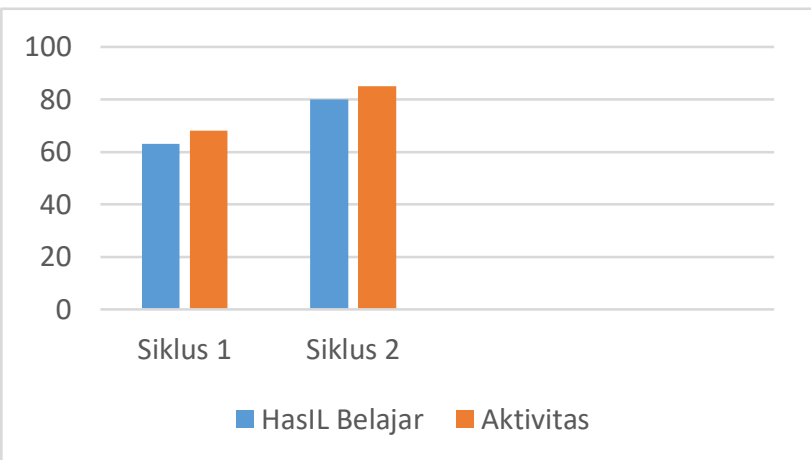

\section{Gambar 1. Diagram Grafik Peningkatan Hasil Belajar dan Aktifitas Siswa}

Kemampuan siswa dalam memahami pelajaran melalui model problem solving dapat dilihat dari hasil tes pada setiap akhir pertemuan diketahui berapa persentase siswa yang mencapai ketuntasan belajar dan berapa persentase yang tidak mencapai ketuntasan belajar. Tes yang diadakan setiap pembelajaran selesai bertujuan untuk mengetahui keberhasilan dan kemampuan siswa dalam menyerap materi pelajaran. Pada siklus I hasil temuan dan revisi dapat disajikan dalam tabel berikut :

Tabel 5. Hasil Temuan dan Revisi Selama Proses Pembelajaran Siklus I

\begin{tabular}{|l|l|l|l|}
\hline No & Refleksi & Hasil Temuan & Revisi \\
\hline 1. & $\begin{array}{l}\text { Aktivitas } \\
\text { Siswa }\end{array}$ & $\begin{array}{l}\text { Siswa belum mampu } \\
\text { sepenuhnya menyelesaikan } \\
\text { masalah/ menemukan cara } \\
\text { penyelesaian masalah. }\end{array}$ & $\begin{array}{l}\text { Siswa harus lebih dibimbing } \\
\text { dalam proses belajar mengajar } \\
\text { agar lebih terarah. }\end{array}$ \\
\hline 2. & Hasil Tes & $\begin{array}{l}\text { Masih ada 11 orang yang } \\
\text { hasil belajarnya belum } \\
\text { mencapai skor ketuntasan } \\
\text { dikarenakan kurang } \\
\text { menyeluruhnya penjelasan } \\
\text { guru kepada siswa }\end{array}$ & $\begin{array}{l}\text { Untuk pertemuan berikutnya, } \\
\text { guru harus bisa menjangkau para } \\
\text { siswa dalam menjelaskan materi } \\
\text { agar semua siswa dapat } \\
\text { mengerti materi yang dipelajari. }\end{array}$ \\
\hline
\end{tabular}

Sedangkan pada siklus II hasil temuan dan revisi dapat disajikan dalam tabel berikut : 
Tabel 6. Hasil Temuan dan Revisi Selama Proses Pembelajaran Siklus II

\begin{tabular}{|l|l|l|l|}
\hline No & Refleksi & Hasil Temuan & Revisi \\
\hline 1. & $\begin{array}{l}\text { Aktivitas } \\
\text { Siswa }\end{array}$ & $\begin{array}{l}\text { Siswa sudah mampu sepenuhnya } \\
\text { menyelesaikan masalah/menemukan } \\
\text { cara penyelesaian masalah. }\end{array}$ & \\
\hline 2. & Hasil Tes & $\begin{array}{l}\text { Masih ada 5 orang siswa yang hasil } \\
\text { belajarnya belum tuntas hal ini } \\
\text { dikarenakan siswa tersebut kurang } \\
\text { teliti melakukan perhitungan ketika } \\
\text { menjawab soal tes siklus II }\end{array}$ & $\begin{array}{l}\text { Guru } \\
\text { menyediakan } \\
\text { khusus waktu } \\
\text { memberikan } \\
\text { bimbingan } \\
\text { siswa yang bepada } \\
\text { tuntas tersebut agar } \\
\text { mencapai ketuntasan } \\
\text { maksimal. }\end{array}$ \\
\hline
\end{tabular}

Berdasarkan hasil penelitian yang diperoleh bahwa sikap siswa terhadap proses pembelajaran cenderung lebih mudah dipahami setelah melalui siklus kedua. Siskap siswa terhadap materi pelajaran juga menunjukkan minat yang meningkat setelah menjalani siklus kedua. Hal ini menunjukkan bahwa siklus kedua dalam pembelajaran akan sangat membantu siswa dalam meningkatkan hasil belajar. Walaupun pada siklus I respon siswa masih rendah, akan tetapi dengan adanya siklus II menunjukkan siswa tertarik dalam proses pembelajaran. Hal ini sesuai dengan penelitian yang dilakukan oleh Rosniar dan Salawati (2018) yang menyatakan bahwa indikator ketercapaian hasil belajar yang ditetapkan sudah terpenuhi yaitu $\geq 76$.Persentase ketuntasan belajar siswa telah mencapai $88 \%$ sehingga sudah melebihi target yang ditetapkan yaitu $85 \%$ siswa memperoleh nilai $\geq 76$, sedangkan aktivitas siswa diperoleh data lebih dari 50\% siswa memperhatikan guru, mengerjakan soal dengan tahapan pemecahan dan berdiskusi dengan teman sebangkunya . Peningkatan hasil belajar ini berdampak pada peningkatan pemahaman siswa atas suatu materi atau konsep mata pelajaran dan peningkatan jumlah siswa yang dapat memperoleh nilai mencapai KKM. Berdasarkan hal tersebut dapat dilihat bahwa dengan penerapan metode pembelajaran problem solving dapat meningkatkan hasil belajar siswa dan minat siswa terhadap materi reaksi redoks

\section{KESIMPULAN}

Berdasarkan hasil analisis siklus I dan II dapat diperoleh gambaran bahwa pembelajaran menggunakan model problem solving tergolong sangat baik dan para siswa lebih aktif. Siswa diberi kesempatan berdiskusi untuk memecahkan masalah, bertanya, mempresentasikan hasil diskusi, dan bersama dengan guru menyimpulkan materi pembelajaran. Respon yang diberikan siswa terhadap model pembelajaran problem solving pada materi reaksi redoks adalah sangat positif.

\section{DAFTAR PUSTAKA}

Arikunto, Suharsimi. (1992). Prosedur Penelitian Suatu Pendekatan Praktik. Jakarta : PT Rineka Cipta

Asrori , Mohammad. (2009). Penelitian Tindakan Kelas. Bandung : Wacana Prima

Rosniar dan Salawati. (2018). Meningkatkan Hasil Belajar Siswa Melalui Metode Pembelajaran Problem Solving Pada Materi Konsep Mol Di Kelas X-3 MAN Rukoh Banda Aceh. Lantanida Journal 6 (2), 169-179 : 1692019 DOI : 10.22373/lj.v

St. Maryam M , Zaid Zainal, Armila . (2019). Penerapan Metode Problem Solving untuk Meningkatkan Hasil Belajar Matematika Siswa Kelas IV UPT SD Negeri 95 Kecamatan Suppa. Jurnal Ilmiah Pendidikan Matematika, 2(1) from https : 
eprints.unm.ac.id

Sudarmo, U. (2013). Kimia untuk SMA Kelas X. Jakarta: PHiBETA.

Sumarno. (2011). Upaya Peningkatan Aktivitas dan Hasil Belajar Konsep Fluida Melalui Penerapan Strategi Siklus PACE Pada Siswa Kelas XI IPA-8 SMA Negeri I Matauli. PTK

Trianto. (2012). Model Pembelajaran Terpadu. Jakarta: PT Bumi Aksara. 